\title{
POTENSI PENULARAN COVID-19 DI DALAM KABIN PESAWAT KOMERSIAL
}

\author{
Syougie $^{*}$, Eri Ferdi Afian ${ }^{* *}$, Widianto ${ }^{* * *}$, Dasti Anditiarina ${ }^{* * * *}$ \\ 1. Program Studi Kedokteran Penerbangan, Departemen Ilmu Kedokteran Komunitas, \\ Fakultas Kedokteran Universitas Indonesia \\ 2. Fakultas Kedokteran Universitas Islam Al-Azhar
}

\begin{abstract}
ABSTRAK
COVID-19 dapat menular dengan mudah dari satu orang ke orang lain. Penularan dapat terjadi di mana saja termasuk dalam penerbangan. Lingkungan di dalam kabin pesawat merupakan lingkungan yang memungkinkan terjadi kontak dekat karena padatnya penumpang. Potensi penularan Covid-19 di lingkungan penerbangan khususnya potensi penularan di dalam kabin pesawat merupakan masalah yang harus diteliti dan ditanggulangi secepatnya. Kabin pesawat merupakan sebuah lingkungan tertutup berventilasi dengan kepadatan penumpang yang berdekatan satu sama lain, serta kondisi lingkungan yang hipobarik dengan kelembaban yang kering. Pesawat komersial mengedarkan ulang setengah dari udara yang ada di dalam kabin pesawat untuk meningkatkan kontrol terhadap sirkulasi kabin, kelembapan, dan membantu efisiensi bahan bakar.
\end{abstract}

Kata Kunci: Penerbangan, COVID-19, Kabin Pesawat.

\section{PENDAHULUAN}

Novel Corona Virus Disease 2019 (COVID-19) pada akhir 2019 telah menyebar dan menyebabkan permasalahan kesehatan di seluruh dunia. COVID-19 mulai menyebar di China pada Desember 2019 dan menyebar dengan cepat. Agen penyebab penyakit tersebut diidentifikasi sebagai corona virus baru bernama Severe acute respiratory syndrome coronavirus 2 (SARS-CoV-2). World Health organization (WHO) pada tanggal 30 Januari 2020 mendeklarasikan
COVID-19 sebagai Public Health Emergency of International Concern (PHEIC) atau kedaruratan kesehatan masyarakat yang meresahkan dunia. Dampak dari kedaruratan kesehatan masyarakat ini telah mempengaruhi negara dan masyarakat dalam hal masalah ekonomi, sosial-psikologis, serta hubungan internasional. WHO pada tanggal 11 Maret 2020 menyatakannya sebagai pandemi.( Hua J, Shaw R, 2020).

Satu miliar orang bepergian menggunakan pesawat udara setiap tahun, 
baik sebagai penumpang maupun awak pesawat. Mobilitas orang yang semakin meningkat dan popularitas transportasi udara telah memperkuat potensi penularan penyakit pada penumpang dan awak pesawat, baik sebelum, selama, maupun setelah penerbangan. Kecurigaan penularan COVID-19 selama penerbangan dapat dilihat pada beberapa laporan, seperti terdapatnya kluster penularan pada penerbangan dari Singapura menuju China pada tanggal 23 Januari 2020 yang menyebabkan 12 penumpang positif COVID-19 dengan 10 penumpang membutuhkan perawatan di rumah sakit, serta terdapatnya kecurigaan penularan COVID-19 di bulan Februari 2020 pada penerbangan dari Republik Afrika Tengah ke Paris, Perancis (Mangili et.al. 2020).

Pengetahuan mengenai COVID-19 masih sangat terbatas. Virulensi virus yang tinggi, belum adanya antivirus dan vaksin yang efektif, serta potensi populasi asimptomatik yang besar membuat pengelolaan COVID-19 menjadi tantangan tersendiri. Potensi penularan COVID-19 di lingkungan penerbangan khususnya potensi penularan di dalam kabin pesawat masih menjadi hal yang terus diteliti dan dipelajari.( Cao W, Li T, 2020).

\section{COVID-19}

COVID-19 ditandai oleh keluhan berupa demam, batuk, kelelahan, sesak napas, dan gejala saluran pernapasan lainnya. COVID-19 disebabkan oleh virus bernama SARS-CoV-2 yang termasuk ke dalam anggota keluarga $\beta$-coronavirus. SARS-CoV-2 memiliki keterkaitan dengan SARS-CoV yang menyebabkan peyakit Severe Acute Respiratory Syndrome (SARS) (memiliki kemiripan sekitar 79\%) dan Middle East Respiratory Syndrome Coronavirus (MERS-CoV) (memiliki kemiripan sekitar 50\%) berdasarkan genome sequencing. SARS$\mathrm{CoV}-2$ menggunakan angiotensinconverting enzyme 2 (ACE2) sebagai reseptor utama yang banyak ditemukan pada endotel pembuluh darah, epitel saluran pernapasan, monosit alveolar, dan makrofag.( Cao W, Li T dan Bi.Q,. at.el. 2020)

SARS-CoV-2 mampu bereplikasi aktif di saluran pernapasan bagian atas, hal ini terlihat dengan didapatkan isolasi virus hidup dari apus tenggorokan dan dapat dideteksinya subgenomic messenger ribonucleic acid (sgRNA) dalam sel-sel saluran pernapasan atas. Pertumbuhan jaringan yang tinggi pada saluran pernapasan bagian atas menjelaskan pelepasan virus secara terus-menerus dari faring serta transmisi SARS-CoV-2 yang lebih efisien daripada SARS-CoV saat gejalanya masih minimal dan terbatas 
pada saluran pernapasan atas.( $\mathrm{Cao} \mathrm{W}, \mathrm{Li}$ T. 2020)

Replikasi SARS-CoV-2 di saluran pernapasan bawah akan menyebabkan infeksi sekunder dan kerusakan pada organ yang mengekspresikan ACE2 seperti jantung, ginjal, saluran pencernaan dan pembuluh darah distal. Peningkatan keparahan penyakit tidak hanya berkaitan dengan kerusakan langsung yang diakibatkan oleh virus tetapi juga akibat dari kerusakan yang dimediasi kekebalan tubuh (immune mediated injury) yang dipicu oleh SARS-CoV-2.( Cao W, Li T. 2020)

Penularan COVID-19 dapat terjadi secara langsung melalui kontak dengan orang yang terinfeksi, atau secara tidak langsung melalui kontak dengan permukaan di lingkungan terdekat orang yang terinfeksi. Penularan SARS-CoV-2 dari orang ke orang lain terjadi melalui droplet pernapasan dan kontak langsung. Penularan melalui droplet terjadi ketika seseorang berada dalam kontak dekat (jarak satu meter) dengan orang yang terinfeksi serta terjadinya paparan terhadap droplet pernapasan, misalnya melalui batuk, bersin, atau kontak pribadi yang sangat dekat yang mengakibatkan virus masuk melaui mulut, hidung atau konjungtiva (mata). Penularan juga dapat terjadi melalui cairan tubuh di sekitar orang yang terinfeksi. WHO menyebutkan bahwa sebagian besar penularan COVID-
19 terjadi dari orang yang bergejala ke orang lain dalam kontak dekat ketika tidak memakai APD yang sesuai. Selain itu, terdapat penularan dari orang yang telah terinfeksi dan mampu melepaskan virus tetapi belum memperlihatkan gejala. (WHO. 2020)

\section{Potensi Penularan COVID-19}

Kabin pesawat merupakan sebuah lingkungan tertutup berventilasi dengan kepadatan penumpang yang berdekatan satu sama lain serta kondisi lingkungan yang hipobarik dengan kelembaban yang kering. Kondisi kabin pesawat diatur oleh sistem lingkungan yang mengontrol tekanan, suhu, ventilasi, dan penyaringan udara pada pesawat. Udara dari luar pesawat disuplai ke kabin pesawat oleh unit daya tambahan. Udara tersebut akan dipanaskan, dikompresi, didinginkan, dan diedarkan ke kabin oleh sistem ventilasi. Udara yang diambil dari luar pada ketinggian jelajah dianggap steril. Pola sirkulasi udara yang standar pada kabin pesawat komersial adalah sirkulasi sideto-side (laminar) dimana udara memasuki kabin dari bagian atas, bersirkulasi melintasi pesawat, dan keluar dari kabin melalui celah di dekat lantai (gambar 1). Aliran udara front-to-back (longitudinal) hanya sedikit terjadi. Pola sirkulasi udara ini membagi aliran udara menjadi beberapa bagian di dalam kabin pesawat, sehingga membatasi penyebaran 
partikulat airborne ke seluruh kabin penumpang.( Mangili. at.el. 2020)

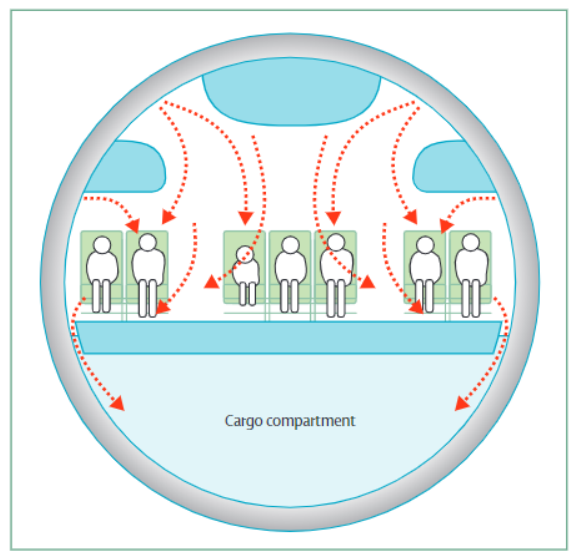

Gambar 1. Pola aliran udara di dalam kabin pesawat penumpang

Pesawat komersial mengedarkan ulang setengah udara yang ada di dalam kabin pesawat untuk meningkatkan kontrol terhadap sirkulasi kabin, dan kelembaban, serta membantu efisiensi bahan bakar. Udara yang disirkulasi ulang ini melewati High Efficiency Particulate Air filter (HEPA filter) sebelum dialirkan kembali ke kabin. Pertukaran udara pada kabin pesawat berkisar antara 15 hingga 20 pertukaran udara per jam bila dibandingkan dengan 12 pertukaran udara per jam pada bangunan kantor biasa. HEPA filter yang digunakan pada pesawat komersial memiliki efisiensi penghilangan partikel $99,97 \%$ pada 0,3 mikron. Filter ini dapat menghilangkan debu, uap, bakteri, dan jamur. HEPA filter juga efektif menangkap partikel virus karena virus biasanya menyebar melalui droplet nuclei.( Mangili. at.al. 2020)

Terdapat sebuah laporan kasus adanya cluster COVID-19 pada penerbangan menuju Bandara Internasional Hangzhou di Zhejiang, China pada tanggal 23 Januari 2020 yang membawa 325 penumpang dan awak pesawat. Seluruh penumpang dan awak pesawat telah menjalani skrining kesehatan yang ketat di bandara di Singapura. Hasil skrining tersebut tidak ada penumpang dan awak pesawat yang tercatat memiliki gejala. Selama penerbangan yang berlangsung selama lima jam, seorang penumpang laki-laki mengalami demam tanpa gejala saluran napas. Penumpang tersebut diketahui tidak memakai masker. Penumpang pesawat yang positif COVID-19 berjumlah 12 penumpang dengan dua penumpang tanpa gejala. Awak pesawat tidak ada yang tertular dan diketahui bahwa awak pesawat menggunakan masker selama penerbangan. Hasil penelusuran selama 14 hari sebelum penerbangan, para penumpang yang positif tidak tercatat memiliki kontak dengan pasien terduga COVID-19 sehingga penularan diduga terjadi di dalam pesawat.( Yang N. at.al. 2020)

Penelitian dari Zhang et.al. terhadap 4492 penumpang yang dicurigai terinfeksi COVID-19 (suspected case) ditemukan dua penumpang positif 
COVID-19 yang mungkin tertular selama penerbangan atau dengan masa inkubasi sebelum naik pesawat. Asumsi bahwa kedua penumpang ini terinfeksi ketika berada di dalam pesawat, attack ratio keseluruhan untuk infeksi COVID-19 di pesawat adalah $0,00014 \%$ (total jumlah penumpang pesawat sebanyak 14.505 penumpang) yang dapat dianggp sebagai risiko yang dapat diabaikan.( Zhang J. at.el. 2020)

Beberapa alasan yang mungkin menyebabkan attack ratio yang rendah, yaitu pertama, hampir setiap penumpang dan awak pesawat menggunakan masker selama berada di dalam pesawat. Tidak ditemukan bukti bahwa penumpang yang terinfeksi adalah karena melepas masker untuk makan dan minum. Kedua, pola sirkulasi udara pada pesawat adalah sideto-side (laminar): udara masuk ke kabin dari atas, bersirkulasi melintasi pesawat, dan keluar dari kabin di dekat lantai secara efektif dapat mencegah penularan penyakit pernafasan di dalam kabin. Ketiga, langkah-langkah pencegahan yang dilakukan di bandara berperan penting untuk mencegah penularan COVID-19.( Zhang J. at.el. 2020)

\section{Pencegahan Penularan COVID-19 Di}

\section{Dalam Kabin Pesawat}

Pencegahan terjadinya transmisi COVID-19 di dalam kabin pesawat harus dimulai sejak di bandara, sebelum pesawat berangkat. Penumpang dan awak pesawat yang akan melakukan perjalanan harus dilakukan skrining kesehatan untuk menjaring penumpang atau awak pesawat yang berpotensi terjangkit COVID-19. Skrining kesehatan ini meliputi pemeriksaan suhu, pemeriksaan tanda dan gejala terkait COVID-19 serta hasil pemeriksaan rapid test atau polymerase chain reaction (PCR) jika diperlukan. Penerapan langkah-langkah pencegahan penularan COVID-19 secara umum seperti physical distancing, penggunaan masker, serta menjaga kebersihan tangan harus tetap dilaksanakan. Pelaksanaan pembersihan dan desinfeksi pesawat harus rutin dilakukan pada pesawat yang beroperasi untuk mencegah penularan melalui benda-benda yang terkontaminasi droplet yang mengandung SARS-CoV-2.( Zhang J. at.el. 2020)

Pemantauan kesehatan awak pesawat yang bertugas harus terus dilaksanakan. Hal tersebut bertujuan untuk melindungi penumpang dan awak pesawat itu sendiri. Beberapa langkah yang dapat dilakukan dalam proses pemantauan kesehatan awak pesawat seperti yang dikeluarkan oleh Federal Aviation Administration (FAA) diantaranya adalah:( FAA. 2020)

1. Awak pesawat memantau diri mereka sendiri terhadap peningkatan suhu badan (merasa demam atau suhu yang diukur $38^{\circ} \mathrm{C}$ atau lebih 
tinggi), batuk, atau sesak napas, atau gejala COVID-19 lainnya. Awak pesawat mengukur suhu mereka dua kali sehari selama masa tugas dan setiap kali mereka merasa sakit.

2. Awak pesawat tinggal di rumah atau kamar hotel dan memberi tahu bagian kesehatan di tempat kerja mereka untuk tidak bekerja jika mereka memenuhi salah satu dari kondisi berikut:

1) Mengalami demam, batuk, napas pendek, atau gejala COVID-19 lainnya, walaupun ringan.

2) Hasil tes positif untuk SARSCoV-2.

3) Terpapar dengan orang yang memiliki gejala COVID-19 meskipun orang tersebut belum dites untuk SARS-CoV-2.

3. Paparan yang menjadi perhatian meliputi:

1) Adanya anggota rumah atau pasangan intim yang sakit.

2) Merawat orang sakit tanpa menggunakan alat pelindung diri (APD).

3) Berjarak enam kaki (dua meter) dari orang yang sakit (termasuk rekan kerja dan penumpang) dalam jangka waktu yang lama yaitu, 10 menit atau lebih lama.

4. Awak pesawat yang memiliki gejala atau terpapar seseorang dengan
COVID-19 tidak boleh kembali bekerja sampai diizinkan kembali kerja oleh bagian kesehatan tempat bekerja dan pejabat kesehatan masyarakat.

5. Awak pesawat yang mengalami gejala selama penerbangan harus berhenti bekerja sesegera mungkin, mengenakan masker bedah atau kain penutup wajah, memberi tahu Petugas Penerbangan Utama atau Purser dan menjaga jarak jarak (dua meter) dari orang lain sejauh mungkin.

Untuk memberikan perlindungan kesehatan bagi awak pesawat dan penumpang, FAA juga merekomendasikan bagi awak pesawat untuk:( FAA. 2020)

1. Pertahankan jarak enam kaki (dua meter) dari orang lain sejauh mungkin, termasuk:

1) Saat bekerja di pesawat terbang, misal saat duduk di kursi saat lepas landas atau mendarat atau bekerja di area dapur.

2) Selama bepergian di darat.

3) Saat berada di tempat umum.

2. Menginap di rumah atau kamar hotel mereka.

1) Makan di kamar hotel selama menginap dengan menggunakan layanan kamar atau layanan pengiriman. Jika pilihan pengiriman makanan dalam 
kamar tidak tersedia, usahakan take-out dari restoran hotel atau restoran lain di dekatnya.

2) Batasi aktivitas di depan umum hanya untuk hal penting, seperti mendapatkan makanan.

3. Sering mencuci tangan dengan sabun dan air setidaknya selama 20 detik, atau gunakan pembersih tangan berbasis alkohol dengan kandungan alkohol 60\%, terutama setelah menyentuh permukaan yang kemungkinan terkontaminasi dengan cairan tubuh setelah batuk, bersin, atau meniup hidung mereka; setelah menggunakan kamar kecil; sebelum makan; dan sebelum menyiapkan atau menyajikan makanan atau minuman; dan setelah melepas APD apa pun, termasuk sarung tangan.

4. Hindari menyentuh mata, hidung, atau mulut dengan tangan yang tidak dicuci.

5. Pertimbangkan untuk mengenakan masker saat berada di sekitar orang lain, terutama dalam situasi mereka tidak dapat menjaga jarak fisik yang direkomendasikan dengan orang lain.

6. Penutup muka kain tidak boleh menggantikan penggunaan masker bedah atau APD lainnya yang terdapat dalam Universal Precaution Kit (UPK) ketika berinteraksi dengan penumpang yang sakit di atas pesawat.
7. Hindari kontak dengan orang yang batuk, demam, atau sesak napas, atau dicurigai menderita COVID-19.

8. Periksa dan konfirmasi kondisi dan isi UPK sebelum penerbangan. Patuhi kebijakan dan prosedur angkutan udara yang ada mengenai penggunaan APD yang tersedia dalam kit jika diperlukan merawat wisatawan yang sakit di atas pesawat.

9. Ikuti panduan untuk tindakan pencegahan COVID-19 dari negara dan otoritas kesehatan setempat di daerah di mana mereka berada.

Sedikit berbeda dengan FAA, Perhimpunan Dokter Spesialis Kedokteran Penerbangan Indonesia (PERDOSPI) menyatakan bahwa physical distancing di dalam kabin pesawat dengan pengurangan pengisian tempat duduk bukan suatu hal yang utama. Penerapan pencegahan lain dalam lingkungan kabin pesawat seperti penggunaan APD dan menjaga kebersihan tangan lebih diutamakan dibandingkan dengan physical distancing. (Perdospi. 2020)

PERDOSPI menyarankan agar masker yang digunakan para penumpang dan awak pesawat selama berada di bandara maupun di dalam kabin pesawat berupa masker standar bedah (surgical mask). Hal tersebut sedikit berbeda dengan panduan penggunaan masker WHO bahwa masker yang digunakan 
pada transportasi umum cukup menggunakan masker non-bedah. Peningkatan standar penggunaan masker perlu dilakukan karena masker kain yang beredar di pasaran sulit untuk dilakukan standardisasi mutu sesuai dengan ketentuan WHO. Penggunaan pelindung wajah (face shield) dapat dipertimbangkan sebagai proteksi tambahan bagi para penumpang. APD tambahan yang disarankan untuk awak pesawat yaitu pelindung wajah (face shield) dan sarung tangan dengan tetap memperhatikan faktor keselamatan.(WHO dan Perdospi. 2020)

\section{PENUTUP}

COVID-19 dapat menular dengan mudah dari satu orang ke orang lain. Penularan dapat terjadi di mana saja termasuk dalam penerbangan. Lingkungan di dalam kabin pesawat merupakan lingkungan yang memungkinkan terjadi kontak dekat karena padatnya penumpang. Langkahlangkah pencegahan untuk mengurangi risiko terjadinya penularan COVID-19 harus dilakukan secara holistik dimulai dari sejak sebelum keberangkatan dengan melakukan skrining kesehatan bagi calon penumpang dan awak pesawat, melakukan pembersihan dan desinfeksi pesawat secara rutin, serta menerapkan berbagai protokol pencegahan seperti memakai masker, menjaga jarak, serta menjaga kebersihan tangan. Ketersediaan APD yang baik dan sesuai standar sangat ditekankan. Pelaksanakan protokol pencegahan yang sesuai standar dan regulasi berlaku di tempat masing-masing dapat menekan potensi penularan COVID-19 di dalam kabin pesawat.

\section{DAFTAR PUSTAKA}

Bi Q, Wu Y, Mei S, Ye C, Zou X, Zhang $Z$, et al. 2020. Epidemiology and transmission of COVID-19 in 391 cases and 1286 of their close contacts in Shenzhen, China: a retrospective cohort study. Lancet Infect Dis. Apr;S1473309920302875.

Cao W, Li T. 2020. COVID-19: towards understanding of pathogenesis. Cell Res. May;30(5):367-9.

Eldin C, Lagier J-C, Mailhe M, Gautret P. 2020. Probable aircraft transmission of Covid-19 in-flight from the Central African Republic to France. Travel Med Infect Dis. Apr;101643.

FAA. 2020. Safety Alerts for Operators. COVID-19: Updated Interim Occupational Health and Safety Guidance for Air Carriers and Crews. Federal Aviation Administration;.

Hua J, Shaw R. 2020. Corona Virus (COVID-19) "Infodemic" and Emerging Issues through a Data Lens: The Case of China. Int J Environ Res Public Health. Mar 30;17(7):2309.

Mangili A, Gendreau MA. Transmission of infectious diseases during commercial air travel. The Lancet. 2005 Mar;365(9463):989-96.

Perdospi. 2020. Rekomendasi Perdospi (Perhimpunan Dokter Spesialis Kedokteran Penerbangan Indonesia) terkai Rencana Penerapan New Normal saat Pandemi Covid-19 di Dunia Penerbangan. 
WHO. 2020. Advice on the use of masks in the context of COVID-19..

Yang N, Shen Y, Shi C, Ma AHY, Zhang $X$, Jian $X$, et al. 2020. In-flight Transmission Cluster of COVID-19: A Retrospective Case Series [Internet]. Infectious Diseases (except HIV/AIDS); Mar [cited 2020 Jun 9]. Available from: http://medrxiv.org/lookup/doi/10.110 1/2020.03.28.20040097

Zhang J, Li J, Wang T, Tian S, Lou J, Kang X, et al. 2020. Transmission of SARS-CoV-2 on Aircraft. SSRN Electron J [Internet]. [cited 2020 Jun 9]; Available from: https://www.ssrn.com/abstract=35866 95 